\title{
Immunochemistry and Lung Cancer: Application in Diagnosis, Prognosis and Targeted Therapy
}

\author{
Aldoph B. Nanguzgambo ${ }^{a}$ Rubina Razack ${ }^{b}$ Mercia Louw ${ }^{b}$ Chris T. Bolliger ${ }^{a}$ \\ a Division of Pulmonology, Department of Medicine, and b Division of Anatomical Pathology, Department of \\ Pathology, Tygerberg Academic Hospital, University of Stellenbosch, Cape Town, South Africa
}

\section{Key Words}

Lung cancer • Immunochemistry $\cdot$ Immunomarker .

Targeted therapy

\begin{abstract}
Immunochemistry is now an established ancillary technique in lung cancer diagnosis. Not only does it help in supporting the morphological diagnosis of malignancy, but its role now extends to the determination of cell lineage, ascertaining the primary site of tumour origin and contributing to decisions on prognosis and treatment. Early detection and confirmation of lung cancer facilitate early treatment decisions. Lung cancer management now has a multidisciplinary approach which includes cytopathologists and clinicians. Some clinicians may not understand what immunochemistry is and what its role is in lung cancer diagnosis, prognosis and therapy. The purpose of this paper is to define immunochemistry, on the background of basic respiratory airway epithelial structure and cancer biology, and discuss its application in the diagnosis, treatment and determination of prognosis of lung cancer.
\end{abstract}

Copyright $\odot 2011$ S. Karger AG, Basel

\section{Background}

Lung cancer remains the commonest global cause of death from cancer [1]. Notable advances in the diagnosis of cancers have been the use of immunochemistry in pathological diagnosis, the characterisation of the poorly differentiated malignant tumour, or in the identification of the origin of the tumour, whether primary or metastatic, and its emerging role in lung cancer prognosis and therapy. Furthermore, lung cancer management has evolved to a multidisciplinary level involving both pathologists and clinicians, some of whom may not understand the ever increasing contribution of immunochemistry to diagnosis, improving targeted therapy and determining prognosis. In this review, we do not discuss the basic principles of immunostaining protocols but focus on the (a) cellular structure of the respiratory airway epithelium and lung cancer biology of the major histological subtypes; (b) definition of immunohistochemistry (IHC) and immunocytochemistry (ICC); (c) common immunomarkers used specifically for primary lung carcinomas, and (d) application of immunochemistry in lung cancer diagnosis, determination of primary origin, and histological subtyping for targeted therapy and prognosis.

\section{KARGER}

Fax +41613061234 E-Mail karger@karger.ch www.karger.com
Aldoph B. Nanguzgambo

Room 3013, 3rd Floor Clinical Building

Faculty of Health Sciences, University of Stellenbosch

Francie van Zil Drive, Tygerberg, Cape Town 7505 (South Africa)

Tel. +27 21938 9423, E-Mail abnanguzgambo@yahoo.co.uk 


\section{Respiratory Airway Epithelial Cells and Lung Cancer Biology}

The respiratory airway is composed of the conducting airways and the acinar airways. The conducting airways comprise the trachea, bronchi, bronchioles and terminal bronchioles. The acinar airway, where gas exchange takes place, is made up of respiratory bronchioles, alveolar ducts and alveolar sacs [2]. The epithelial lining of the respiratory airways is continuous but with variable composition in its cellular structure.

The bronchial epithelium is composed of the following cell types: (a) ciliated columnar cells; (b) basal cells which are cuboidal cells and in contact with the basal membrane; (c) secretory cells, namely goblet cells and serous cells, and (d) myoepithelial cells. Secretory cells produce mucus which is composed of mucins [3].

The epithelium of bronchioles is mainly made up of (a) ciliated cells as in the bronchi, and (b) Clara cells. Besides being secretory cells, Clara cells have been shown to have multiple functions, including xenobiotic metabolism via the cytochrome P450 monooxygenase system and progenicity for ciliated cells in bronchioles when there is epithelial injury [4-6].

The acinar airway epithelium has two cell types: (a) alveolar type I cells, and (b) cuboidal secretory cells, also called alveolar type II cells. Alveolar type II cells synthesise and secrete surfactant apoproteins SP-A, SP-B and SP-C, differentiated by the weight of the protein content of surfactant $[7,8]$.

The respiratory airway epithelium also has neuroendocrine cells. They are part of the amine precursor uptake and decarboxylation (APUD) system and also secrete the enzyme neuron-specific enolase, which is a marker for the diffuse endocrine system. Like other APUD cells, they produce various polypeptide hormones including serotonin, gastrin-releasing peptide, bombesin, calcitonin and chromogranins [9-11].

The natural expectation is that external stimuli such as cigarette smoke initiate neoplastic changes at a cellular and nuclear level in the epithelial cell lines, leading to premalignant lesions which then evolve to lung cancer. Loss of heterozygosity, gene amplification (numeric gain in chromosomal content), chromosomal aneusomy, genetic alterations such as p53 and K-ras, epidermal growth factor receptor (EGFR), and vascular endothelial growth factor receptor mutations with overexpression of the genes have all been implicated in lung cancer evolution [12-17].

Squamous cell carcinoma is believed to be a result of proliferation of basal cells in the respiratory epithelium, which then undergo metaplastic change to squamous cells. This metaplastic cellular morphology is termed bronchial dysplasia. Based on morphological features, bronchial epithelial dysplasia has been categorised into four types, namely mild dysplasia, moderate dysplasia, severe dysplasia and carcinoma in situ $[15,18-20]$. It is important to distinguish squamous cell carcinoma from squamous metaplasia and pulmonary infarct, which may present with similar cytomorphological features [21].

The precursor lesion for adenocarcinoma is thought to be atypical adenomatous hyperplasia (AAH), which is also found peripherally [22-25]. By definition, AAH is $\leq 0.5$ $\mathrm{cm}$ and comprises proliferation of atypical type II pneumocytes with gaps between the cells. It is also clear that $\mathrm{AAH}$ represents the premalignant stage of nonmucinous bronchioloalveolar carcinoma (BAC), another peripherally located lesion. It must be noted that in the new proposed classification of lung adenocarcinoma, the term BAC will be withdrawn and replaced by adenocarcinoma in situ (AIS) and minimally invasive adenocarcinoma (MIA), due to a $100 \%$ disease-free survival after complete resection of these preinvasive lesions [26]. In terms of size, both AIS and MIA are defined as being $\leq 3 \mathrm{~cm}$ with lepidic growth pattern, but MIA has an invasive component of $\leq 0.5 \mathrm{~cm}$ in the greatest dimension of each focus. Both lesions are usually nonmucinous. In addition to AIS and MIA, other new terms that will be used to describe BAC depending on the morphology include lepidic predominant adenocarcinoma (nonmucinous), adenocarcinoma predominantly invasive with some nonmucinous lepidic components, and invasive mucinous adenocarcinoma (formerly mucinous BAC) [26]. Using IHC, it has been demonstrated that some adenocarcinomas actually arise centrally, and that these centrally derived tumours do not derive from AAH. On the contrary, peripherally derived adenocarcinomas have similar immunohistochemical and EGFR mutational patterns to AAH [27]. These peripherally derived adenocarcinomas have a cellular morphology similar to that of terminal respiratory epithelial cells (type II pneumocytes, Clara cells and nonciliated bronchiolar cells). Adenocarcinoma must be distinguished from goblet cell hyperplasia, reactive or atypical bronchial epithelial cells, granular cell tumour and hamartoma [21].

Diffuse idiopathic neuroendocrine hyperplasia (DIPNEH) is the precursor lesion of some neuroendocrine cancers, namely carcinoid tumourlets (small neuroendocrine lesions $<0.5 \mathrm{~cm}$ extending beyond the basement membrane) as well as typical and atypical carcinoid tumours. DIPNEH is a result of proliferation of the neuroendocrine cells already described above. Despite small 
Table 1. Advantages and disadvantages of cytological specimens

\begin{tabular}{ll}
\hline Advantages & Disadvantages \\
\hline Easier and safer method to acquire specimens & Numerous artefactual variables in specimens, e.g. blood or necrosis \\
Reduced time to diagnosis & Limited specimen material \\
Easier access to difficult lesions & High degree of cell loss \\
Appropriate for patients not fit for biopsy & Lack of a cytology control for quality assurance \\
\hline
\end{tabular}

cell lung carcinoma (SCLC) and large cell neuroendocrine carcinoma (LCNEC) having neuroendocrine properties, their cell line origins are not from DIPNEH and are currently not established. There are studies that showed different immunohistochemical reactions [28, 29] and different gene expression profiles [30] between DIPNEH-derived tumours and the more aggressive neuroendocrine tumours (SCLC and LCNEC), suggesting differences in origin.

\section{What Is Immunohisto/Cytochemistry?}

IHC and ICC involve the study of histological (tissue) or cytological (smear) specimens, respectively, using an antibody-antigen immune reaction, the antibody being externally added to the antigen already present on the tissue or smear specimen being analysed. Immunochemical markers can be used to stain cell surface markers, cell membranes, cytoskeletal components, vesicles and other organelles as well as nuclear contents. This immunostaining reaction may be unique to that tissue and its site of origin. Tissue-specific monoclonal antibodies or immunomarkers are now available, and these have helped improve the identification of neoplasms.

Although morphology is still the mainstay of diagnosis in cytopathology with $85-90 \%$ of cases being diagnosed with routine stains such as Papanicolaou and Diff Quik, the remaining 10-15\% require ancillary techniques, of which immunochemistry solves $50 \%$ of the cases [31]. Immunochemistry is indicated in four settings, namely (a) to help establish malignancy; (b) to determine cell lineage; (c) to ascertain the primary site of tumour origin, and (d) for prognostic and therapeutic assessment. Most of the principles which govern the application of IHC to surgical specimens can be applied to cytopathology, with a few adaptations and precautions.

Immunochemistry can be done on whole tissue specimens, fine needle aspiration smears, cytospins of fluids, or cell blocks. Cell blocks are the more optimal specimen on which ICC should be performed [32]. Cell blocks meet the same conditions as tissue sections and accommodate inbuilt controls on the same slide. It has also been shown that ICC can successfully be applied to Papanicolaou-stained smears [33, 34]. Furthermore, cell blocks have been successfully prepared directly from scraping of already stained cytology smears, with very good preservation of the morphology and architectural structure. ICC results on these cytoscrape cell block preparations have been shown to be excellent, to be comparable to conventional cell block results and to help in achieving the final diagnosis [35].

The major advantage of performing ICC over IHC pertains to specimen acquisition. Fine needle aspiration is easy, safe and can deliver a diagnosis within minutes. However, cytological specimens have their own drawbacks (table 1). It is essential that results be interpreted in close correlation with cytomorphological, clinical and radiological findings. ICC must be seen as a complementary to reaching a definite diagnosis, never the qualifier. If any discrepancies are encountered in the above regard, a formal biopsy must be acquired and IHC must be performed. However, even IHC is ancillary and does not replace morphology. A larger repeat biopsy may need to be obtained if there is any doubt about the diagnosis.

\section{What Are the Useful Available Immunomarkers for Identifying the Origin of Lung Carcinomas?}

Table 2 shows the commonly used immunomarkers in lung cancer diagnosis.

\section{Thyroid Transcription Factor-1}

Thyroid transcription factor-1 (TTF-1) is a $38-\mathrm{kDa}$ homeodomain-containing nuclear transcription protein belonging to the Nkx2 gene family. TTF-1 is involved in the transcription of thyroglobulin and thyroperoxidase genes in the follicular thyroid cells, and of the surfactant $\mathrm{A}, \mathrm{B}, \mathrm{C}$ protein genes and Clara cell secretory protein in lung epithelial cells [36, 37]. In a study by Sturm et al. [38], 
Table 2. Common immunomarkers: indications and predominant histological subtype correlation

\begin{tabular}{lll}
\hline Indication & Immunomarker & $\begin{array}{l}\text { Predominant histology correlation } \\
\text { (positive immunoreactivity) }\end{array}$ \\
\hline Establishing malignancy & p53 & preinvasive dysplastic lesions, \\
& e.g. autofluorescence bronchoscopic specimens \\
& Ki-67 & \\
\hline Determination of primary site of origin & TTF-1 & ADC and nonmucinous BAC \\
& napsin A & ADC \\
& CK7 $5 / 6$ & ADC \\
& CK20 & Sq-CC \\
& $34 \beta E 12$ & Non-pulmonary tumour \\
& p63 & Sq-CC \\
& chromogranin A & Sq-CC \\
& synaptophysin & NE, SCC and LCNEC \\
& NCAM & NE, SCC and LCNEC \\
& vimentin & NE, SCC and LCNEC \\
& desmin & Mesenchymal origin \\
\hline prognosis & EGFR exon mutational antibodies & Mesenchymal origin \\
\hline
\end{tabular}

$\mathrm{ADC}=$ Adenocarcinoma; $\mathrm{Sq}-\mathrm{CC}=$ squamous cell carcinoma; $\mathrm{SCC}=$ small cell carcinoma; $\mathrm{NE}=$ neuroendocrine tumours $(\mathrm{typical}$ and atypical carcinoids).

normal bronchiolar epithelia showed nuclear staining of Clara cells, whilst bronchial epithelial cells (basal cells and mucoserous glands) were negative. Normal and hyperplastic alveolar type II cells were strongly positive for TTF-1. It is expressed in all types of thyroid carcinoma except for the anaplastic type. TTF-1 is now also widely used to identify neoplasms of lung origin.

\section{Cytokeratins}

Cytokeratins (CKs) are water-soluble intracellular proteins found on most epithelial cells and are part of the intermediate filament family. There are at least 20 subclasses based on their molecular weight and isoelectric $\mathrm{pH}$ value (Moll's catalogue) [39]. Examples of useful CK immunomarkers used to identify the origin of lung neoplasms include CK7, CK20, 34ßE12 which recognises CK1, $-5,-10$ and -14 of Moll's catalogue, and CK5/6 [40]. The combination of CK7 and CK20 is commonly used to establish the pulmonary origin of a neoplasm, based on the differential diagnosis and clinical history. CK7 is a $5-\mathrm{kDa}$ basic protein strongly expressed in different epithelia including the breast, endometrium, bladder, pancreas, biliary tract, stomach, and lung [40,41]. CK20 is a $46-\mathrm{kDa}$ acid protein located in the epithelium of the intestine, bladder, pancreas and biliary tract as well as in
Merkel cells [42-44]. A lung tumour with CK20-positive immunoreactivity strongly suggests a metastatic carcinoma rather than a primary lung malignancy. However, mucinous adenocarcinoma of the lung may also express CK20 positivity, especially mucinous BAC $[45,46]$. The $34 \beta E 12$ monoclonal antibody is a highly sensitive marker of normal epithelial basal and parabasal cells and their proliferations [38].

\section{Neuroendocrine Immunomarkers}

Neuroendocrine immunomarkers are used for identifying tumours of neuroendocrine origin such as SCLC. They include chromogranin A, synaptophysin and neural cell adhesion molecule (NCAM). Chromogranin A is part of the chromogranin family of acidic glycoproteins. Synaptophysin is located in the neuronal presynaptic vesicles and is also positive in paraganglioma, thyroid medullary carcinoma, endocrine pancreatic tumours and carcinoid tumours. NCAM (CD56) is part of the intercellular adhesion molecule family that binds cells together. It is found on neurons, astrocytes, Schwann cells, myoblasts and natural killer lymphocytes. Among neoplasms, it is mainly expressed in neuroendocrine carcinomas [47] but also in some aggressive lymphomas such as natural killer/T-cell lymphoma with cutaneous involvement [48]. 


\section{Other Immunomarkers}

Surfactant apoproteins A and B antibodies have been used to establish the pulmonary origin of lung cancer. Their sensitivity was only $63 \%$ in detecting primary lung cancers, with a specificity of $46 \%[49,50]$. p63 and p53 belong to the family of transcription factors. Early and frequent genomic amplification of p63 has been demonstrated in the development of squamous cell lung carcinoma. p63 genomic sequence amplification was seen in $88 \%$ of squamous cell carcinomas, $42 \%$ of large cell carcinomas and $11 \%$ of adenocarcinomas [51]. Napsin A is a functional aspartic proteinase expressed in normal lung parenchyma in type II pneumocytes and in the proximal and convoluted tubules of the kidneys [52]. It is strongly positive in $80 \%$ of lung adenocarcinomas. Napsin A has been reported to show a stronger, more diffuse and more sensitive expression than TTF-1 and to stain $11 \%$ more lung adenocarcinomas than TTF-1. It stains negative for squamous cell carcinoma and small cell carcinoma of the lung [49]. Ki-67 is a DNA-binding nuclear protein expressed throughout the cell cycle in proliferating cells but not in quiescent cells [53]. Ki-67 immunomarkers such as MIB-1 have been used to assess prognosis in non-small cell lung carcinoma (NSCLC), as will be discussed later.

\section{How Are Immunomarkers Applied in Lung Cancer?}

\section{Establishing the Presence of Malignancy in a}

Tissue Sample

Establishing malignancy is always based on morphological features of a cytological or histological specimen. It may, however, not be feasible to morphologically diagnose lung cancer or classify lung tumours accurately due to factors such as inadequate cytology or biopsy specimens or presence of artefacts [54]. The role of immunochemistry in confirming malignancy is still limited. It remains an ancillary technique that supports the morphological diagnosis and does not independently establish a diagnosis of malignancy. Wang et al. [20] showed various degrees of positive immunostaining for CKs, p53 and $\mathrm{Ki}-67$ in the four categories of bronchial epithelial dysplasia, with Ki-67 showing more widespread expression and stronger staining than $\mathrm{p} 53$. The degree and extent of dysplasia was positively correlated with the incidence of bronchogenic carcinoma $(p<0.05)$. Another study on p63 in 43 preinvasive lesions showed that p63 immunostaining increases progressively throughout the depth of epithelia from metaplasia to severe dysplasia [51]. In this study, however, genomic amplification of the p63 copy number gain was notable in high-grade dysplasia $(n=13)$, similar to the copy number gain in the adjacent invasive squamous cell carcinoma, while low-grade preinvasive lesions did not demonstrate a 663 copy number gain even if these lesions were in the vicinity of the invasive tumour. The authors concluded that due to its direct correlation with pathological dysplastic grading, p63 immunostaining is less effective than p63 genomic amplification in detecting early tumourigenesis [51]. Nowadays, autofluorescence bronchoscopy is able to detect abnormal mucosa, and biopsies can be taken from these areas; however, these biopsy specimens may not confirm overt malignancy but only show morphological dysplastic changes $[55,56]$. Immunomarkers such as p53, p63 and Ki67 may be useful in such instances to establish the preinvasive process and therefore support the decision-making process regarding prognosis and therapy.

\section{Determination of the Primary Site of Tumour Origin and the Cell Line}

It must be stated that different pathology laboratories use different immunomarker panels to establish the primary site of tumour origin and the possible cell line. Rossi et al. [54] stated that the most currently validated immunomarkers for refining most diagnoses are TTF-1 and/or CK7 for adenocarcinomas and p63 and the highmolecular-weight CKs $(-1,-4,-5,-6,-10,-11,-14)$ for squamous cell carcinomas.

\section{Adenocarcinoma and BAC}

TTF-1 is now widely used to identify adenocarcinomas of pulmonary origin, with a sensitivity of 75-94\% and a specificity of $100 \%$ [57]. In one study, 23 out of 26 (88.5\%) adenocarcinomas showed strong nuclear staining with TTF-1 antibody [38]. In another study, 12 out of $14(85.7 \%)$ pleomorphic tumours with an adenocarcinomatous component showed immunoreactivity for TTF-1 [58]. TTF-1 is also positive in nonmucinous BAC. This reflects the common precursor origin from $\mathrm{AAH}$, which is a terminal respiratory unit lesion. It has been shown that TTF-1 is negative in $25 \%$ of adenocarcinomas, especially in those that are centrally derived as well as in mucinous BAC [27, 59]. CK7 is also useful in identifying adenocarcinomas of pulmonary origin. Typically, an adenocarcinoma of pulmonary origin will stain positive for CK7 but negative for CK20 [41, 54]. As discussed above, CK20 is not expressed in the epithelium of the respiratory airways and is therefore used to discriminate adenocarcinomas from the gastrointestinal tract or the urothelium $[43,44,60]$. As mentioned earlier, napsin A can also 
be used to identify primary pulmonary adenocarcinoma. For example, napsin A has been used to identify primary pulmonary adenocarcinomas from adenocarcinomas from other organs $[61,62]$.

\section{Squamous Cell Carcinoma}

As discussed above, the precursor cell of squamous cell carcinoma is believed to be the epithelial basal cell. $34 \beta E 12$ is a useful antibody for identifying squamous cell tumours of basal cell origin. It is positive in all basaloid carcinomas, basaloid variants of squamous cell carcinomas and in squamous cell carcinomas. Sturm et al. [38] showed a $100 \%$ sensitivity for $34 \beta E 12$ in all the abovementioned carcinomas compared to about $31 \%$ in adenocarcinomas. The authors concluded that $34 \beta E 12$ appears to be a specific marker for neoplasms arising from reserve cells of the bronchial epithelium, recognizing a wide spectrum of epithelial tumours including basaloid carcinoma, squamous cell carcinoma, basaloid variant of squamous cell carcinoma and some adenocarcinomas. Other markers used for positive identification of squamous cell carcinoma include CK5/6 and p63, although none of these have a $100 \%$ sensitivity or specificity. Squamous cell carcinoma typically stains negative for TTF-1 $[38,63]$. Furthermore, Wang et al. [20] showed that all four categories of bronchial epithelial dysplasia were negative for TTF-1, surfactant apoprotein A, chromogranin A and synaptophysin.

\section{Small Cell Carcinoma}

As described above, the precursor origin of small cell carcinoma has not been established and seems different from those of other neuroendocrine tumours. However, small cell carcinoma shares common features with other neuroendocrine tumours on immunochemistry. It stains positive for chromogranin A, synaptophysin and NCAM CD56 [64, 65]. Morphologically, it may sometimes be difficult to distinguish between small cell carcinoma and other pulmonary neuroendocrine tumours such as carcinoid tumours due to crush artefact. Crush artefact is a known characteristic of small cell carcinomas, regardless of their origin [66]. In such cases, immunostaining with Ki-67 has helped discriminate between these two tumour groups, with small cell carcinomas showing more than $25 \%$ immunoreactivity in the crushed areas compared to less than $10 \%$ for carcinoid tumours [67]. TTF- 1 has a sensitivity of about $75-80 \%$ in SCLC. In a study by Ordonez [63], 27 of 28 (96\%) SCLC were TTF-1 positive compared to 4 out of $54(7 \%)$ of non-pulmonary small cell carcinomas. CK20 which stains positive in non-pulmonary small cell carcinomas such as Merkel cell carcinomas is useful in discriminating between the two malignancies [68]. $34 \beta E 12$ is always negative in small cell carcinoma and, if positive, may suggest histological heterogeneity in combination with a non-small cell tumour [29].

\section{Large Cell Carcinoma}

Large cell carcinoma is a tumour with no differentiation to allow classification into squamous cell carcinoma, adenocarcinoma or small cell carcinoma. In the WHO classification of tumours of the lung [18], several subtypes of large cell carcinoma exist. The two common subtypes are LCNEC and basaloid carcinoma. LCNEC has immunochemical properties similar to small cell carcinoma and other neuroendocrine tumours. In a study by Sturm et al. [38], the sensitivities in LCNEC of chromogranin A, synaptophysin and NCAM were 68.5, 84.2 and $91.2 \%$, respectively. The sensitivity of TTF-1 expression in LCNEC ranges from $50-75 \%[69,70]$, and therefore, TTF- 1 is not helpful in differentiating LCNEC from solid adenocarcinomas in which TTF-1 also stains positive. The monoclonal antibody $34 \beta E 12$ is negative in LCNEC. It is known that LCNEC can exist in pure forms or in combined forms with squamous cell carcinoma. When this happens, $34 \beta E 12$ is positive. The basaloid large cell carcinoma is identified by the specific staining with $34 \beta E 12$ monoclonal antibody (as discussed above for cancers of basal cell origin) and negative staining with neuroendocrine markers. One study [38] found that all 28 cases of basaloid carcinoma expressed $34 \beta E 12$ but were negative for TTF-1.

\section{Neuroendocrine Tumours}

This group includes neuroendocrine hyperplasia, carcinoid tumourlets and typical and atypical carcinoid tumours. They all stain positive for the common neuroendocrine immunomarkers discussed above. Neuronspecific enolase is no longer considered useful in the identification of neuroendocrine tumours, as it has been found to be expressed in some non-neuroendocrine tumours [71]. To establish the pulmonary origin of neuroendocrine tumours, TTF- 1 has been used, but the sensitivity ranges from 35 to $94 \%[63,72-74]$. In the study by Du et al. [57] on immunoreactivity of TTF-1 in neuroendocrine tumours from the lung, thymus, gastrointestinal tract, pancreas, and ovary, TTF-1 expression was shown in 10 out $36(27.8 \%)$ pulmonary typical carcinoids and in $29.4 \%$ of pulmonary atypical carcinoids compared to complete none reactivity (0\%) in extrapulmonary typical and atypical carcinoid tumours. On the contrary, other authors reported negative staining for TTF-1 in all carci- 
noid tumourlets as well as in typical and atypical carcinoid cases [75]. Du et al. [57] argued that this observed difference in TTF-1 reactivity was multifactorial and cited reasons such as differences in methodology and antibody concentrations used, differences in scoring for intensity and extent of stain as well as possible differences in the location of the tumours analysed, that is whether central or peripherally derived.

\section{Sarcomatoid Carcinoma}

This is a group of carcinomas with an epithelial origin combined with varying degrees of mesenchymal differentiation [76]. The tumours have either mixed components of spindle cells or giant cells or other mesenchymal elements but can also occur in pure forms. They have been described not only in the lung but also in the skin, breast, urogenital and gastrointestinal tract [77]. The WHO histological subtypes include pleomorphic carcinoma, giant cell carcinoma, spindle cell carcinoma, carcinosarcoma and pulmonary blastoma [18]. The immunomarkers MNF116, AE1/AE3 and epithelial membrane antigen are used to confirm their epithelial origin. TTF-1 and other CKs can be used to identify the specific carcinomatous components of either adenocarcinoma or squamous cell carcinoma. Rossi et al. [58] found positive staining for TTF-1 and CK7 in $43 \%$ and $62.7 \%$, respectively, of sarcomatoid carcinomas with spindle and/or giant cell components, whereas the pure carcinosarcoma and pulmonary blastoma had negative immunoreactivity with these immunomarkers. Immunomarkers for mesenchymal tissue such as vimentin or desmin can be used to identify the mesenchymal elements. The morphological appearance is important to identify the sarcomatous elements in the specimen, and a cytological specimen may be inadequate for such tumours.

\section{Therapeutic and Prognostic Applications}

It is now no longer helpful to define a lung cancer generally as NSCLC or poorly differentiated NSCLC, and efforts must be made to specify the histological subtype. Current evidence has confirmed that establishing the exact histological subtype has therapeutic and prognostic implications. Studies comparing pemetrexed-based regimens with non-pemetrexed regimens have shown improved response rates, progression-free survival and overall survival in patients with non-squamous cell histology (adenocarcinoma and large cell carcinoma) compared to patients with squamous cell carcinoma $[19,78]$. Furthermore, studies have revealed that patients with lung adenocarcinomas that have EGFR mutations show better survival rates when treated with EGFR tyrosine kinase inhibitors (gefitinib and erlotinib) than with conventional cytotoxic therapy [79]. Angiogenesis inhibitors such as bevacizumab and sunitinib have been associated with an increased risk of haemorrhagic adverse effects when used in patients with squamous cell carcinoma compared to non-squamous NSCLC $[19,78]$. The management of NSCLC has now evolved to optimising individually targeted therapy and addressing safety issues based on histological subtypes, and not on staging and performance status alone [78].

Although fluorescence in situ hybridization and mutational analysis are commonly used to identify which lung carcinomas, especially adenocarcinomas, are amenable to targeted therapy, immunochemistry is now being extended to this field as well, particularly in identifying EGFR mutations. The EGFR family comprises 4 transmembrane receptors belonging to the tyrosine receptor superfamily, and EGFR activation promotes tumour proliferation, angiogenesis and metastasis [80]. Twenty percent of lung adenocarcinomas exhibit EGFR mutations and $90 \%$ of EGFR mutations occur in exon 19 (15-bp/5-aa deletion) and exon 21 (L858R point mutation) [81]. Other EGFR mutations associated with sensitivity to anti-EGFR therapy are G719 mutations in exon 18 and L861 mutations in exon 21, but these are less common [81]. The gold standard method of detecting EGFR mutations is by molecular analysis with direct DNA sequencing. However, direct DNA sequencing has its own limitations which include the need for a good specimen size with a good turnover of tumour cells for DNA extraction, its high cost and a methodological complexity resulting in its use only in academic centres and commercial laboratories [82]. Specific antibody immunomarkers have now been developed targeting these EGFR exon mutants. A study of two antibodies against these exon mutants showed different sensitivities and predictive values depending on the cutoff point selected according to the immunohistochemical staining grading scale of 0 to 3 . At a cutoff point of $1+$, the sensitivity for the L858R antibody was $95 \%$ with a positive predictive value (PPV) of $99 \%$, while at a cutoff value of $2+$, the sensitivity decreased to $76 \%$ with a PPV of $100 \%$. For the exon 19 deletion 15-bp/ 5-aa antibody, the sensitivity and PPV were 85 and 99\%, respectively, at a cutoff value of $1+$ and 67 and $100 \%$, respectively, at a cutoff point of $2+$ [83]. The authors, however, advised that in cases where the antibody tests were negative or inconclusive, EGFR molecular testing should still be performed. They concluded that EGFR mutantspecific antibodies should be included in the workup of 
lung adenocarcinoma to allow more rapid initiation of EGFR tyrosine kinase inhibitor therapy, and lead to a modest reduction in the volume of molecular testing [83]. A different study, however, showed a much lower overall sensitivity of $47 \%$ for these mutation-specific antibodies (L858R and del E746-A750 in exon 19), with an overall specificity of $96 \%$ [84]. The low sensitivity in this study was attributed to cross-reactivity of these antibodies with other mutations in exon 18 (G719C), exon 19 (del L747T751 ins Q), exon 20 (A769 ins ASV) for the L858R antibody and exon 20 (D770 ins SVD) for the anti-del E746A750 antibody. Furthermore in this study, one of two lung cancers with the EGFR wild type had positive immunoreactivity despite absence of any EGFR mutation. The authors concluded that even though these antibodies have good specificity, their low sensitivity implies that not all patients with EGFR mutations can be selected using these mutation-specific antibodies, and therefore clinical utility may be less than expected [84].

Anti-Ki-67 has been analysed in the determination of prognosis of lung cancer. In a meta-analysis of 37 studies on lung cancer, of which 29 were on NSCLC, expression of Ki-67 in resected NSCLC specimens was a poor prognostic factor for patients with stages I-III, even in subgroup analysis of histological subtypes [53]. On the contrary, Yang et al. [85] found no correlation between Ki-67 expression and prognosis in NSCLC stage I-IIIA. Such variable findings in the prognostic value of $\mathrm{Ki}-67$ in NSCLC have been attributed to factors such as patient heterogeneity, retrospective nature of the study design, quantification of IHC and different cutoff values [86].

\section{Conclusion}

Understanding the basic histology of the respiratory airways as well as their cell structure and composition has led to further understanding the possible cell line origins of primary lung neoplasms. Targeting the basic cellular antigens, immunochemistry has not only improved the diagnosis of lung cancer but also shed light on the histogenesis of some of the primary lung cancers. Using immunochemistry techniques, primary lung carcinoma can now be distinguished from a metastatic carcinoma. However, further studies are required to consolidate the role of immunochemistry in guiding targeted therapy in lung cancer and determining prognosis.

\section{Disclosure Statement}

The authors have no conflicts of interest to declare.

\section{References}

1 Jemal A, Siegel R, Ward E, Hao Y, Xu J, Murray T, Thun MJ: Cancer statistics, 2008. CA Cancer J Clin 2008;58:71-96.

2 Weibel ER: Design of airways and blood vessels considered as branching trees; in Crystal RG, West BJ, Weibel ER, Barnes PJ (eds): The Lung: Scientific Foundations. Philadelphia, Lippincott-Raven, 1997, pp 1061-1071.

3 Kuhn C: The cytology of the lung: ultrastructure of the respiratory epithelium and extracellular lining layers; in Farrell MP (ed): Lung Development: Biological and Clinical Perspectives. London, Academic Press Inc, 1982, pp 27-55.

4 Plopper CG, Hyde DM, Buckpitt AR: Clara cells; in Crystal GR, West JB, Weibel E, Barnes PJ (eds): The Lung: Scientific Foundations. Philadelphia, Lippincott-Raven, 1997, pp 517-533.

5 Plopper CG, Dungworth DL: Structure, function, cell injury and cell renewal of bronchiolar and alveolar epithelium; in McDowell EN (ed): Lung Carcinoma. London, Churchill Livingstone, 1987, pp 29-44.
6 Devereux TR, Domin BA, Philpot RM: Xenobiotic metabolism by isolated pulmonary cells. Pharmacol Ther 1989;41:243-256.

7 Mason RJ, Shannon JM: Alveolar type II cells; in Crystal GR, West JB, Weibel E, Barnes PJ (eds): The Lung Scientific Foundations. Philadelphia, Lippincott-Raven, 1997, pp 543-555.

8 Van Golde LMG, Batenburg JJ, Robertson B: The pulmonary surfactant system: biochemical aspects and functional significance. Physiol Rev 1988;68:374-455.

9 Hage E: Morphology and histochemistry of the normal and abnormal pulmonary endocrine cell; in Becker KL, Gazdar AF (eds): The Endocrine Lung in Health and Disease. Philadelphia, WB Saunders, 1984, pp 193-209.

10 Scheuermann DW: Morphology and cytochemistry of the endocrine epithelial system in the lung. Int Rev Cytol 1987;106:35-88.

11 Schmechel D, Marangos PJ, Brightman M: Neuron-specific enolase is a molecular marker for peripheral and central neuroendocrine cells. Nature 1978;276:834-836.
12 Franklin WA: The biology of bronchial premalignancy. Semin Respir Crit Care Med 1996; 17:309-321.

13 Zhang X, Chang A: Somatic mutations of the epidermal growth factor receptor and nonsmall cell lung cancer. J Med Genet 2007;44: 166-172.

14 Lynch TJ, Bell DW, Sordella R, Gurubhagavatula $S$, Okimoto RA, Brannigan BW, Harris PL, Haserlat SM, Supko JG, Haluska FG, Louis DN, Christiani DC, Settleman J, Haber DA: Activating mutations in the epidermal growth factor receptor underlying responsiveness of non-small cell lung cancer to gefitinib. N Engl J Med 2004;350:2129-2139.

15 Kerbel RS: Tumour angiogenesis. N Engl J Med 2008:358:2039-2049.

16 Kitaguchi S, Takeshima Y, Nishisaka T, Inai K: Proliferative activity, p53 expression and loss of heterozygosity on $3 p, 9 p$ and $17 p$ in atypical adenomatous hyperplasia of the lung. Hiroshima J Med Sci 1998;47:17-25. 
17 Breuer RH, Pasic A, Smit EF, van Vliet E, Vonk Noordegraaf A, Risse EJ, Postmus PE, Sutedja TG: The natural course of preneoplastic lesions in bronchial epithelium. Clin Cancer Res 2005;11:537-543.

18 Travis W, Brambilla E, Muller-Hermelink HK, Harris CC: Pathology and Genetics of Tumours of the Lung, Pleura, thymus and Heart. World Health Organization Classification of Tumours. Lyon, IARC Press, 2004.

-19 Rossi A, Maione P, Bareschino MA, Schettino C, Sacco PC, Ferrara ML, Castaldo V, Gridelli C: The emerging role of histology in the choice of first-line treatment of advanced non-small cell lung cancer: implication in the clinical decision-making. Curr Med Chem 2010;17:1030-1038.

-20 Wang GF, Lai MD, Yang RR, Chen PH, Su YY, Lv BJ, Sun LP, Huang Q, Chen SZ: Histological types and significance of bronchial epithelial dysplasia. Mod Pathol 2006;19: 429-437.

-21 Idowu MO, Powers CN: Lung cancer cytology: potential pitfalls and mimics - a review. Int J Clin Exp Pathol 2010;3:367-385.

-22 Jackson EL, Willis N, Mercer K, Bronson RT, Crowley D, Montoya R, Jacks T, Tuveson DA: Analysis of lung tumor initiation and progression using conditional expression of oncogenic K-ras. Genes Dev 2001;15:32433248.

-23 Miller RR, Nelems B, Evans KG, Muller NL, Ostrow DN: Glandular neoplasia of the lung: a proposed analogy to colonic tumors. Cancer 1988;61:1009-1014.

-24 Westra WH, Baas IO, Hruban RH, Askin FB, Wilson K, Offerhaus GJA, Slebos RJC: K-ras oncogene activation in atypical alveolar hyperplasias of the human lung. Cancer Res 1996;56:2224-2228.

25 Kitamura H, Kameda Y, Nakamura N, Nakatani Y, Inayama Y, Iida M, Noda K, Ogawa N, Shibagaki T, Kanisawa M: Proliferative potential and p53 overexpression in precursor and early stage lesions of bronchioloalveolar lung carcinoma. Am J Pathol 1995;146:876887.

-26 Travis WD, Brambilla E, Noguchi M, Nicholson AG, Geisinger RK, Yatabe Y, Beer DG, Powell CA, Reily JG, Van Schil PE, Garg K, Austin JHM, et al: International association for the study of lung cancer/american thoracic society/european respiratory society international multidisciplinary classification of lung adenocarcinoma. J Thorac Oncol 2011;6:244-285.

-27 Yatabe Y, Kosaka T, Takahashi T, Mitsudomi T: EGFR mutation is specific for terminal respiratory unit type adenocarcinoma. Am J Surg Pathol 2005;29:633-639.

-28 Fabbro D, Di Loreto C, Stamerra O, Beltrami CA, Lonigro R, Damante G: TTF-1 gene expression in human lung tumours. Eur J Cancer 1996;32A:512-517.
9 Sturm N, Rossi G, Lantuejoul S, Laverriere $\mathrm{MH}$, Papotti M, Brichon PY, Brambilla C, Brambilla E: $34 \beta E 12$ expression along the whole spectrum of neuroendocrine proliferations of the lung, from neuroendocrine cell hyperplasia to small cell carcinoma. Histopathology 2003;42:156-166.

30 Anbazhagan R, Tihan T, Bornman DM, Johnston JC, Saltz JH, Weigering A, Piantadosi S, Gabrielson E: Classification of small cell lung cancer and pulmonary carcinoid by gene expression profiles. Cancer Res 1999; 59:5119-5122.

31 Turbat-Herrera EA, D’Agostino H, Herrera GA: The use of electron microscopy to refine diagnoses in the daily practice of cytopathology. Ultrastruct Pathol 2004;28:55-66.

32 Suthipintawong C, Leong AS, Vinyuvat S: Immunostaining of cell preparations: A comparative evaluation of common fixatives and protocols. Diagn Cytopathol 1996;15:167-174.

33 Abendroth CS, Dabbs DJ: Immunocytochemical staining of unstained versus previously stained cytologic preparations. Acta Cytol 1995;39:379-386.

34 Travis WD, Wold LE: Immunoperoxidase staining of fine needle aspiration specimens previously stained by the Papanicolaou technique. Acta Cytol 1986;31:517-520.

35 Bhatia P, Dey P, Uppal R, Shifa R, Srinivasan R, Nijhawan R: Cell blocks from scraping of cytology smear: comparison with conventional cell block. Acta Cytol 2008;52:329-333.

-36 Civitareale D, Lonigro R, Sinclair AJ, Di Lauro R: A thyroid-specific nuclear protein essential for tissue-specific expression of the thyroglobulin promoter. EMBO J 1989;8: 2537-2542.

37 Katoh R, Miyagi E, Nakamura N, Li X, Suzuki K, Kakudo K, Kobayashi M, Kawaoi A Expression of thyroid transcription factor-1 (TTF-1) in human C cells and medullary carcinomas. Hum Pathol 2000;31:386-393.

-38 Sturm N, Lantuejoul S, Laverriere MH, Papotti M, Brichon PY, Brambilla C, Brambilla E: Thyroid transcription factor 1 and cytokeratins 1, 5, 10, 14 (34ßE12) expression in basaloid and large-cell neuroendocrine carcinomas of the lung. Hum Pathol 2001;32: 918-925.

39 Moll R, Franke WW, Schiller DL, Geiger B Krepler R: The catalogue of human cytokeratins: patterns of expression in normal epithelia, tumours and cultured cells. Cell 1982; 31:11-24.

40 Chu PG, Weiss LM: Keratin expression in human tissues and neoplasms. Histopathology 2002;40:403-439.

41 Ramaekers F, van Niekerk C, Poels L, Schaafsma E, Huijsmans A, Robben H, Schaart G, Vooijs P: Use of monoclonal antibodies to keratin 7 in the differential diagnosis of adenocarcinoma. Am J Pathol 1990;136:641655.
42 Moll R, Löwe A, Laufer J, Franke WW: Cytokeratin 20 in human carcinomas. A new histodiagnostic marker detected by monoclonal antibodies. Am J Pathol 1992;140:427-447.

43 Hamden P, Allam A, Joyce AD, Patel A, Selby P, Southgate J: Cytokeratin 20 expression by non-invasive transitional cell carcinomas: potential for distinguishing recurrent disease. Histopathology 1995;27:169-174.

44 Miettinen M: Keratin 20: immunohistochemical marker for gastrointestinal, urothelial, and Merkel cell carcinomas. Mod Pathol 1995;8:384-388.

45 Shah RN, Badve S, Papreddy K, Schindler S, Laskin WB, Yeldandi AV: Expression of cytokeratin 20 in mucinous bronchioloalveolar carcinoma. Hum Pathol 2002;33:915-920.

46 Saad RS, Cho P, Silverman JF, Liu Y: Usefulness of $\mathrm{Cdx} 2$ in separating mucinous bronchioloalveolar adenocarcinoma of the lung from metastatic mucinous colorectal adenocarcinoma. Am J Clin Pathol 2004;122:421427.

47 Rosai J: Special techniques in surgical pathology; in Rosai J (ed): Ackerman's Surgical Pathology, 8th edition. St. Louis, Mosby, 1996, pp 29-62.

48 Mraz-Gernhard S, Natkunam Y, Hoppe RT, LeBoit P, Kohler S, Kim KH: Natural killer/ natural killer-like T-cell lymphoma, CD56+, presenting in the skin: an increasingly recognized entity with an aggressive course. J Clin Oncol 2001;19:2179-2188.

49 Jagirdar J: Application of immunohistochemistry to the diagnosis of primary and metastatic carcinoma to the lung. Arch Pathol Lab Med 2008;132:384-396.

50 Bejarano PA, Baughman RP, Biddinger PW, Miller MA, Fenoglio-Preiser C, al-Kafaji B, Di Lauro R, Whitsett JA: Surfactant proteins and thyroid transcription factor-1 in pulmonary and breast carcinomas. Mod Pathol 1996;9:445-452.

51 Massion PP, Taflan PM, Jamshedur Rahman SM, Yildiz P, Shyr Y, Edgerton EM, Westfall MD, Roberts JR, Pietenpol JA, Carbone DP, Gonzalez AL: Significance of p63 amplification and overexpression in lung cancer development and prognosis. Cancer Res 2003; 63:7113-7121.

52 Mori K, Shimizu H, Konno A, Iwanaga T: Immunohistochemical localization of napsin and its potential role in protein catabolism in renal proximal tubules. Arch Histol Cytol 2002;65:359-368.

53 Martin B, Paesmans M, Mascaux C, Berghmans T, Lothaire P, Meert AP, Lafitte JJ, Sculier JP: Ki-67 expression and patients survival in lung cancer: systematic review of the literature with meta-analysis. Br J Cancer 2004;91:2018-2025. 
54 Rossi G, Pelosi GP, Graziano P, Barbareschi M, Papotti M: A reevaluation of the clinical significance of histological subtyping of non-small-cell lung carcinoma: diagnostic algorithms in the era of personalized treatments. Int J Surg Pathol 2009;17:206-218.

55 Lam B, Wong MP, Fung SL, Lam DC, Wong PC, Mok TY, Lam FM, Ip MS, Ooi CG, Lam WK: The clinical value of autofluorescence bronchoscopy for the diagnosis of lung cancer. Eur Respir J 2006;28:915-919.

-56 Kennedy TC, McWiliams A, Edell E, Sutedja T, Downie G, Yang R, Gazdar A, Mathur PN, American College of Chest Physicians: Bronchial intraepithelial neoplasia/early central airways lung cancer: ACCP evidence-based clinical practice guidelines (2nd edition). Chest 2007;132(3 suppl):221S-233S.

57 Du EZ, Goldstraw P, Zacharias J, Tiffet O, Craig PJ, Nicholson AG, Weidner N, Yi ES: TTF-1 expression is specific for lung primary in typical and atypical carcinoids: TTF-1positive carcinoids are predominantly in peripheral location. Hum Pathol 2004;35:825831.

58 Rossi G, Cavazza A, Sturm N, Migaldi M, Facciolongo N, Longo L, Maiorana A, Brambilla E: Pulmonary carcinomas with pleomorphic, sarcomatoid, or sarcomatous elements: a clinicopathologic and immunohistochemical study of 75 cases. Am J Surg Pathol 2003;27:311-324.

59 Brambilla E, Lantuejoul S: Pathology and immunohistochemistry of lung cancer; in Spiro SG, Huber RM, Janes SM (eds): Thoracic Malignancies. European Respiratory Society Monograph, 2009, vol 44, pp 15-35.

60 Wang NP, Zee S, Zarbo RJ, Bacchi CE, Gown AM: Coordinate expression of cytokeratins 7 and 20 defines unique subsets of carcinomas. Appl Immunohistochem 1995;3:99107.

-61 Yang M, Nonaka D: A study of immunohistochemical differential expression in pulmonary and mammary carcinomas. Mod Pathol 2010;23:654-661.

-62 Bishop JA, Sharma R, IIIei PB: Napsin A and thyroid transcription factor-1 expression in carcinomas of the lung, breast, pancreas, colon, kidney, thyroid, and malignant mesothelioma. Hum Pathol 2010;41:20-25.

63 Ordoónez NG: Value of thyroid transcription factor-1 immunostaining in distinguishing small cell lung carcinomas from other small cell carcinomas. Am J Surg Pathol 2000;24:1217-1223.
64 Lantuejoul S, Moro D, Michalides RJAM, Brambilla C, Brambilla E: Neural cell adhesion molecules (NCAM) and NCAM-PSA expression in neuroendocrine tumours. Am J Surg Pathol 1998;22:1267-1276.

65 Brambilla E, Lantuejoul S, Sturm N: Divergent differentiation in neuroendocrine lung tumors. Semin Diagn Pathol 2000;17:138148.

66 Azzopardi JG: Oat-cell carcinoma of the bronchus. J Pathol Bacteriol 1959;78:513519.

67 Aslan DL, Gulbahce HE, Pambuccian SE, Manivel JC, Jessurun J: Ki-67 immunoreactivity in the differential diagnosis of pulmonary neuroendocrine neoplasms in specimens with extensive crush artifact. Am J Clin Pathol 2005;123:874-878.

68 Chan JKC, Suster S, Wenig BM, Tsang YW, Chan JB, Lau AL: Cytokeratin 20 immunoreactivity distinguishes Merkel cell (primary cutaneous neuroendocrine) carcinoma and salivary gland small cell carcinomas from small cell carcinomas of various sites. Am J Surg Pathol 1997;21:226-234.

69 Folpe AL, Gown A, Lamps LW, Garcia R, Dail DH, Zarbo RJ, Schmidt RA: Thyroid transcription factor-1: immunohistochemical evaluation in pulmonary neuroendocrine tumors. Mod Pathol 1999;12:5-8.

70 Kaufmann O, Dietel M: Expression of thyroid transcription factor-1 in pulmonary and extrapulmonary small cell carcinoma and other neuroendocrine carcinomas of various primary sites. Histopathology 2000;36:415420.

71 Pahlman S, Esscher T, Nilsson K: Expression of $\gamma$-subunit of enolase, neuron-specific enolase, in human non-neuroendocrine tumors and derived cell lines. Lab Invest 1986;54: 554-560.

72 Agoff SN, Lamps LW, Philip AT, Amin MB, Schmidt RA, True LD, Folpe AL: Thyroid transcription factor-1 is expressed in extrapulmonary small cell carcinomas but not in other extrapulmonary neuroendocrine tumors. Mod Pathol 2000;13:238-242.

73 Cai YC, Banner B, Glickman J, Odze RD: Cytokeratin 7 and 20 and thyroid transcription factor 1 can help distinguish pulmonary from gastrointestinal carcinoid and pancreatic endocrine tumors. Hum Pathol 2001;32: 1087-1093

74 Zamecnik J, Kodet R: Value of thyroid transcription factor-1 and surfactant apoprotein A in the differential diagnosis of pulmonary carcinomas: a study of 109 cases. Virchows Arch 2002;440:353-361.
75 Sturm N, Rossi G, Lantuejoul S, Papotti M, Franchon S, Claraz C, Brichon PY, Brambilla C, Brambilla E: Expression of thyroid transcription factor-1 in the spectrum of neuroendocrine cell lung proliferations with special interest in carcinoids. Hum Pathol 2002; 33:175-182.

76 Wick MR, Swanson PE: Carcinosarcomas: current perspectives and historical review of nosological concepts. Semin Diagn Pathol 1993;10:118-127.

$>77$ Mc Menamin ME, Goh SG, Poblet E, Gostelow BE, Robson A, Calonje E: Sarcomatoid basal cell carcinoma - predilection for osteosarcomatous differentiation: a series of 11 cases. Am J Surg Pathol 2006;30:1299-1308.

78 West H, Harpole D, Travis W: Histologic considerations for individualized systemic therapy approaches for the management of non-small cell lung cancer. Chest 2009;136: 1112-1118.

79 Sequist LV, Joshi VA, Jänne PA, Muzikansky A, Fidias P, Meyerson M, Haber DA, Kucherlapati R, Johnson BE, Lynch TJ: Response to treatment and survival of patients with nonsmall cell lung cancer undergoing somatic EGFR mutation testing. Oncologist 2007;12: 90-98.

80 Minna JD, Gazdar AF, Sprang SR, Herz J: Cancer, a bull's eye for targeted lung cancer therapy. Science 2004;304:1458-1461.

-81 Sharma SV, Bell DW, Settleman J, Haber DA: Epidermal growth factor receptor mutations in lung cancer. Nat Rev Cancer 2007;7:169181.

82 Ladanyi M, Pao W: Lung adenocarcinoma: guiding EGFR-targeted therapy and beyond. Mod Pathol 2008;21:S16-S22.

83 Brevet M, Arcila M, Ladanyi M: Assessment of EGFR mutation status in lung adenocarcinoma by immunohistochemistry using antibodies specific to the two major forms of mutant EGFR. J Mol Diagn 2010;12:169-176.

84 Kitamura A, Hosoda W, Sasaki E, Mitsudomi T, Yatabe Y: Immunohistochemical detection of EGFR mutation using mutationspecific antibodies in lung cancer. Clin Cancer Res 2010;16:3349-3355.

85 Yang J, Ramnath N, Moysich KB, Asch HL, Swede H, Alrawi SJ, Huberman J, Geradts J, Brooks JSJ, Tan D: Prognostic significance of MCM2, Ki-67 and gelsolin in non-small cell lung cancer. BMC Cancer 2006;6:203.

86 Pugsley JM, Schmidt RA, Vesselle H: The Ki67 index and survival in non-small cell lung cancer: a review and relevance to positron emission tomography. Cancer J 2002;8:222233. 